\title{
Assessment of Genetic Variability and Correlation for Yield and its Components Traits in Durum Wheat (Triticum durum Desf.)
}

\author{
Abhay Dashora ${ }^{1 *}$, Urmila $^{1}$, Arun Gupta ${ }^{2}$ and Champa Lal Khatik ${ }^{3}$ \\ ${ }^{1}$ Department of Plant Breeding and Genetics, Directorate of Research, \\ MPUAT, Udaipur, India \\ ${ }^{2}$ ICAR-IIWBR, Karnal, Haryana, India \\ ${ }^{3}$ Plant Breeding \& Genetics, ARS, Fatehpur-Shekhawati, Sikar, India \\ *Corresponding author
}

Key w o r d s
$\begin{aligned} & \text { Correlation, path } \\ & \text { coefficient analysis, } \\ & \text { variability, wheat }\end{aligned}$
Article Info
$\begin{aligned} & \text { Accepted: } \\ & 15 \text { May } 2020 \\ & \text { Available Online: } \\ & \text { 10 June } 2020\end{aligned}$

\section{A B S T R A C T}

Genetic variability, heritability, correlation and path analysis were estimated among 59 accessions of 08 quantitative characters in durum wheat. The highest value of GCV and PCV were observed for grain yield per plot, tillers per meter row length, spike length, grains per spike and test grain weight. It is also observed that the traits like grain yield per plot, tillers per meter row length, grains per spike and test grain weight exhibited high GCV also possesses high genetic gain indicating preponderance of additive gene effect for these traits. In corollary to high heritability, estimates of genetic advance as per cent of mean was also observed for indicating predominance of additive gene effects for these traits. In the present investigation grain yield was positively and significantly correlated with plant height, grains per spike and spike length. The path coefficient analysis revealed that grains per spike had maximum positive direct effect on grain yield followed by spike length and plant height. Therefore, greater emphasis should be given on these characters while selecting for higher yield and related traits.

\section{Introduction}

Durum wheat (Triticum durum Desf.), a member of poaceae family, is second most cultivated species of wheat globally as well as nationally, after bread wheat. It is the only tetraploid (AABB, $2 n=4 x=28$ ) species of wheat which has commercially a great importance and carries raw material of numerous foods such as macaroni and semolina in alimentation of world population and it is a promising and viable alternative crop for farmers (Shewry, 2009). The world's durum wheat acreage and production are concentrated in West Asia, North Africa, Canada, Mexico, India and Mediterranean Europe. Durum is pre-dominantly spring wheat, although winter durum is also grown 
to a limited extent. Worldwide, durum wheat is grown approximately over 13 million hectares with an approximate annual production of 30 million toneswhich contributes less than $5 \%$ of the world's wheat production.

Development of high yielding cultivars requires knowledge of the existing genetic variation and also extent of association among yield contributing traits. Superior genotypes can be isolated by selection, if considerable genetic variability exists in the population. The genetic variability along with heritability gives a reliable picture of the genetic advance to be expected for selections while the heritability, coupled with genetic advance aids in predicting the valuable conclusion for effective selection based on phenotypic performance.

Grain yield of wheat, being a complex character, is a function of several component characters and their interaction with environment. Correlation and path coefficient analysis together give a clear cut picture of inter-relationship and relative contribution of independent characters on dependent variable which enables to a plant breeder to apply suitable selection procedures for crop improvement.

Keeping this in view, the present investigation was made to explore the genetic variability, by determining the magnitude of genotypic coefficient of variation, heritability estimates and expected genetic advance of different traits, their correlation and effects in 59 durum wheat accessions.

\section{Materials and Methods}

The experimental materials consisted of 55 genotypes along with 4 checks. The experiment was laid out in Augmented Randomized Block Design with 5 blocks where each block contains 11 test entries and 4 checks (randomly allocated) with the total of 15 genotypes in each block atInstructional Agronomy Farm, Rajasthan College of Agriculture, Maharana Pratap University of Agriculture and Technology, Udaipurduring rabi, 2018-19, Each genotype was sown in 2 rows of $2.5 \mathrm{~m}$ length keeping row to row distance of $23 \mathrm{~cm}$.

All the recommended packages of practices were followed to raise a good crop. The observations were recorded on five randomly selected plants from each genotype in each block for traits viz., plant height, number of tillers per meter, grain per spike, spike length, 1000-grain weight and grain yield per plot, while for days to heading and days to maturity, the data was recorded on whole plot basis.

For augmented block design, analysis of variance was done by using the method given by Federer (1956). The phenotypic and genotypic coefficient of variation (Burton, 1952), heritability (Burton and Devane,1953) and genetic advance (Johnson et al., 1955) were computed. The correlation coefficients were calculated as per the methods given by Al Jibouri et al., (1958) and path coefficient analysis according to Dewey and Lu (1959).

\section{Results and Discussion}

The analysis of variance indicated significant difference among genotypes for most of the traits studied indicating presence of significant variability in the experimental materials (Table-1). The range, mean, phenotypic coefficient of variation (PCV), genotypic coefficient of variation (GCV), heritability $\left(\mathrm{h}^{2}\right)$ in broad sense, genetic advance (GA) and genetic gain as per cent of mean for various characters are presented in Table-2. The range of variability indicated the existence of variability for all the characters. 
In general, PCV values were relatively higher than respective GCV values indicating influence of environment on the expression of the character. The estimated of PCV and GCV indicated the existence of fairly high degree of variability. The highest value of GCV and PCV were observed forgrain yield per plot, tillers per meter row length,spike length, grains per spike and 1000-grain weight.

Lower values of GCV and PCV were recorded in days to maturity, days to heading and plant height indicating the important role of environment in the expression of the character. High magnitude of PCV and GCV was also observed for grain yield per plot by Joshi et al., (2018), Mohammadi et al., (2012), Tambe et al., (2013) and Dhakar et al., (2012).

These results indicating the presence of ample variability for grain yield and related traits in wheat. This observation draws supports from the very high value of heritability $(>80 \%)$ recorded for these traits viz., grain yield per plot, tillers per meter row length and test grain weight (Table-2). It is also observed that the traits like grain yield per plot, tillers per meter row length, grains per spike and test grain weight exhibited high GCV also possesses high genetic gain indicating preponderance of additive gene effect for these traits. In corollary to high heritability, estimates of genetic advance as per cent of mean was also observed for indicating predominance of additive gene effects for these traits.

Yield of a crop is the result of interaction of a number of inter-related characters. Therefore, selection should be based on these components characters after assessing their correlation with yield. Correlation revealed the mutual relationship between two characters and it is important parameter for taking a decision regarding the nature of relation to be followed for improvement in the crop under study. The genotypic and phenotypic correlation among the yield and yield components in durum wheat are presented in Table-3. Significant correlation of characters suggested that there is much scope for direct and indirect selection for further improvement. In general, the estimates of genotypic correlation coefficient were higher than their corresponding phenotypic one, thereby suggesting strong inherent association among the characters studied. In the present investigation grain yield per plot was positively and significantly correlated with plant height, grains per spike and spike length. Therefore, these characters should be considered while making selection for yield improvement in durum wheat (Table-3). Similar trends of results were supported by Abdul et al., (2014) and Sakhare et al., (2011) reported positive correlation of most of the traits with grain yield per plot.

As the correlation coefficients are not sufficient to explain true relationship for an effective manipulation of the characters, path coefficients were worked out. The path coefficient analysis helps in separating the direct effect of a component characters on yield from indirect effects via other traits.

The result of path analysis presented in table 4 revealed that grains per spike and spike length had maximum positive direct effect on grain yield. These finding are in agreement with Deshmukh et al., (2009) and Yagdi (2009). Grains per spike and Spike length had significant positive correlation with grain yield through its direct effect. The same finding was reported by Abinasa et al., (2011). The significant positive correlation of plant height was through indirect effect via spike length. The value of residual effect (0.72) indicates that there may be some other secondary components that should not be ignored. 
Table.1 Analysis of variance for different characters in durum wheat using Augmented Randomized Block Design

\begin{tabular}{|c|c|c|c|c|c|c|}
\hline Character & $\begin{array}{c}\text { Block } \\
{[4]}\end{array}$ & $\begin{array}{c}\text { Treatment } \\
{[58]}\end{array}$ & $\begin{array}{c}\text { Check (C) } \\
{[3]}\end{array}$ & $\begin{array}{c}\text { Genotype (G) } \\
{[54]}\end{array}$ & $\begin{array}{c}\mathrm{C} \text { v/s G } \\
{[1]}\end{array}$ & $\begin{array}{c}\text { Error } \\
{[12]}\end{array}$ \\
\hline Days to Maturity & 2.88 & $10.23 *$ & 8.98 & $10.44 *$ & 2.85 & 3.44 \\
\hline Tillers per meter row & $438.93 *$ & $724.92 * *$ & $1276.58 * *$ & $657.16^{* *}$ & $2729.09 * *$ & 130.63 \\
\hline Grains/ spike & 174.08 & 170.93 & 257.12 & 168.37 & 50.69 & 77.91 \\
\hline 1000+-grain weight & 0.66 & $47.12 * *$ & $185.01 * *$ & $39.46 * *$ & $47.32 * *$ & 3.12 \\
\hline Grain yield per plot & 5805.00 & $41413.14^{* *}$ & 20973.33 & $38495.40 * *$ & $260290.56^{* *}$ & 6248.33 \\
\hline
\end{tabular}

Figure in parenthesis are degree of freedom

$*, * *$ represent significant at $5 \%$ and $1 \%$ level of significance respectively

Table.2 Variability parameters for different characters in durum wheat

\begin{tabular}{|c|c|c|c|c|c|c|c|c|c|}
\hline \multirow[t]{2}{*}{ Character } & \multicolumn{2}{|c|}{ Range } & \multicolumn{2}{|c|}{ Mean } & \multirow{2}{*}{$\begin{array}{l}\text { Phenotypic } \\
\text { Coefficient of } \\
\text { Variation } \\
(\%)\end{array}$} & \multirow{2}{*}{$\begin{array}{c}\text { Genotypic } \\
\text { Coefficient of } \\
\text { Variation } \\
(\%)\end{array}$} & \multirow{2}{*}{$\begin{array}{l}\text { Heritability } \\
\quad(\%)\end{array}$} & \multirow{2}{*}{$\begin{array}{c}\text { Genetic } \\
\text { Advance } \\
(\% \text { of } \\
\text { mean) }\end{array}$} & \multirow{2}{*}{$\begin{array}{l}\text { Genetic } \\
\text { Gain }\end{array}$} \\
\hline & Genotypes & Checks & Genotypes & Checks & & & & & \\
\hline Days to Heading & $77-90$ & $82.20-86.80$ & 83.98 & 84.80 & 4.25 & 3.43 & 65.09 & 4.78 & 5.69 \\
\hline Days to Maturity & $119-130$ & $122.80-125.80$ & 124.31 & 124.75 & 2.60 & 2.13 & 67.03 & 4.46 & 3.59 \\
\hline Plant Height (cm) & $80-100$ & $81.20-89.60$ & 87.22 & 85.00 & 5.39 & 3.61 & 44.89 & 4.34 & 4.98 \\
\hline Tillers per meter row & $45-175$ & $70.80-106.40$ & 104.09 & 90.45 & 24.63 & 22.04 & 80.12 & 42.31 & 40.65 \\
\hline Grains per spike & $35-88$ & $54.80-69.40$ & 60.51 & 58.65 & 21.44 & 15.72 & 53.73 & 14.36 & 23.73 \\
\hline $\begin{array}{l}1000 \text { Grain } \\
\text { Weight (g) }\end{array}$ & $35.10-67.90$ & $49.70-62.85$ & 54.94 & 56.74 & 11.43 & 10.97 & 92.09 & 11.92 & 21.69 \\
\hline Spike length (cm) & $4.00-10.00$ & $6.20-7.80$ & 6.56 & 7.20 & 20.68 & 14.73 & 50.72 & 1.42 & 21.61 \\
\hline $\begin{array}{l}\text { Grain yield per plot } \\
\text { (g) }\end{array}$ & $120-1025$ & 376-530 & 585.22 & 452.00 & 33.53 & 30.69 & 83.77 & 338.57 & $\mathbf{5 7 . 8 5}$ \\
\hline
\end{tabular}


Table.3 Genotypic (rg) and phenotypic (rp) correlation coefficients between different traits in durum wheat

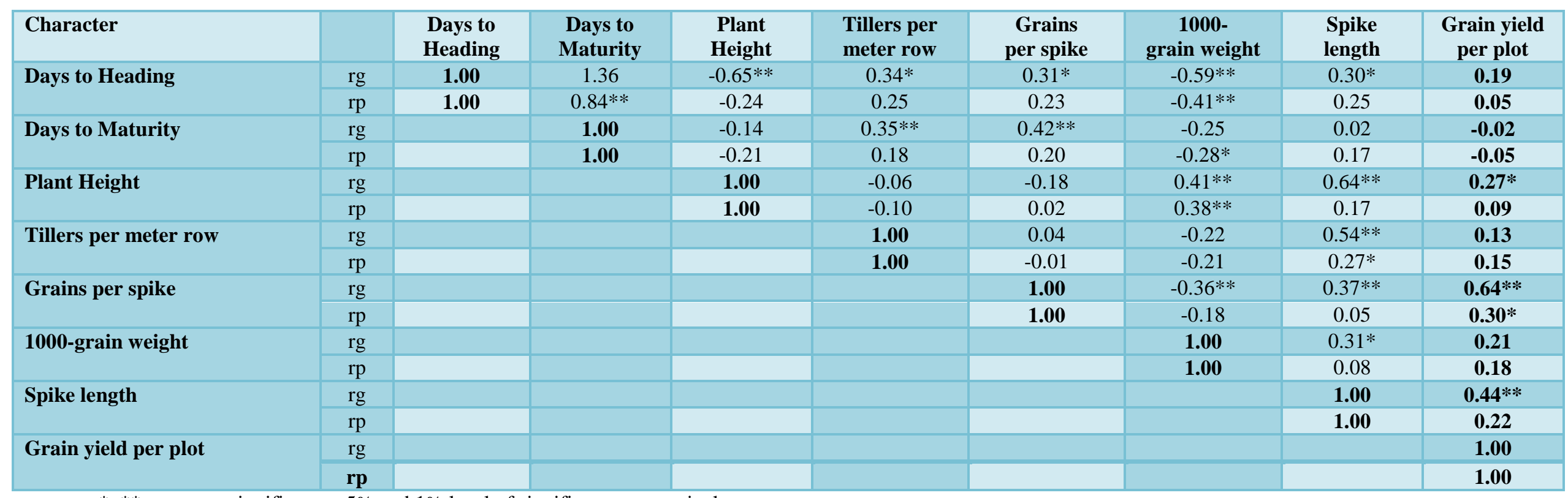

$*$,** represent significant at $5 \%$ and $1 \%$ level of significance respectively

Table.4 Path coefficient analysis indicating direct and indirect effects of various component traits on grain yield in durum wheat

\begin{tabular}{|l|c|c|c|c|c|c|c|c|}
\hline \multicolumn{1}{|c|}{ Character } & $\begin{array}{c}\text { Days to } \\
\text { Heading }\end{array}$ & $\begin{array}{c}\text { Days to } \\
\text { Maturity }\end{array}$ & $\begin{array}{c}\text { Plant } \\
\text { Height }\end{array}$ & $\begin{array}{c}\text { Tillers per } \\
\text { meter row }\end{array}$ & $\begin{array}{c}\text { Grains } \\
\text { per spike }\end{array}$ & $\begin{array}{c}\text { 1000- } \\
\text { Grain weight }\end{array}$ & $\begin{array}{c}\text { Spike } \\
\text { length }\end{array}$ & $\begin{array}{c}\text { Correlation coefficient } \\
\text { with grain yield }\end{array}$ \\
\hline Days to Heading & $\mathbf{- 0 . 3 5}$ & 0.32 & 0.07 & 0.01 & 0.19 & -0.13 & 0.09 \\
\hline Days to Maturity & -0.47 & $\mathbf{0 . 2 3}$ & 0.02 & 0.01 & 0.25 & -0.06 & 0.01 \\
\hline Plant Height & 0.23 & -0.03 & $\mathbf{- 0 . 1 1}$ & -0.00 & -0.11 & 0.09 & 0.20 & $\mathbf{0 . 1 9}$ \\
\hline Tillers per meter row & -0.12 & 0.08 & 0.01 & $\mathbf{0 . 0 2}$ & 0.03 & -0.05 & 0.17 & $\mathbf{0 . 0 2}$ \\
\hline Grains per spike & -0.11 & 0.10 & 0.02 & 0.00 & $\mathbf{0 . 6 0}$ & -0.08 & 0.11 \\
\hline 1000-grain weight & 0.20 & -0.06 & -0.04 & -0.01 & -0.21 & $\mathbf{0 . 2 3}$ & 0.10 & $\mathbf{0 . 1 3}$ \\
\hline Spike length & $\mathbf{- 0 . 1 0}$ & $\mathbf{0 . 0 0}$ & $\mathbf{- 0 . 0 7}$ & $\mathbf{0 . 0 1}$ & $\mathbf{0 . 2 2}$ & $\mathbf{0 . 0 7}$ & $\mathbf{0 . 2 1}$ \\
\hline
\end{tabular}

Residual $=0.7291$ 
In the light of above findings, it may be concluded that improvement in the characters like grains per spike and spike length should be considered for yield improvement in durum wheat breeding programme.

\section{Acknowledgement}

The Authors are thankful to the Director, ICAR-Indian Institute of Wheat and Barley Research, Karnal, Haryana for providing the seed materials for research along with the Director Research, DOR, MPUAT, Udaipur for providing facility for research work.

\section{References}

Abdul, B., Shahla, K. B., Siraj, A. C., Abdul, M. B., Ali, M., Masood, A. J. and Gul, M. B.2014. Character association and heritability analysis in elite bread wheat cultivars. International Journal of Applied Biology and Pharmaceutical Technology, 5(2): 216-233.

Abinasa, M., Ayana, A.and Bultosa, G. 2011. Genetic variability, heritability and trait associations in durum wheat genotypes. African Journal of Agricultural Research, 6(17), 3972-17.

Al-Jibouri, H.A., Miller, P.A. and Robinson, H.F.1958. Genotypic and environmental variances in upland cotton cross of interspecific origin. Agron. J., 50: 633-635.

Burton, G.W. and Devane, E.M.1953. Estimation of heritability in tall fescue. Agron. J. 45:47881.

Burton, G.W.1952. Quantitative inheritance of grasses. Proc. $6^{\text {th }}$ Int. Grassland Corg. 1:22781.

Deshmukh, P. B., Wankhade, R. S., Patil, R. K. and Atale, S. B.2009. Path analysis in durum wheat. Annals of Plant Physiology, 23 (2): 270-271.
Dewey R.D and LU K.H.1959.A correlation and path analysis of components of crested wheatgrass seed production. 51(9); 515-518

Dhakar,M.R., Jat, B.L.Bairwa, L.N. and Gupta, J.K., 2012. Genetic variability in wheat

(Triticum species). Environment and Ecology, 30(4A):1474-1480.

Fedrer, W.T.1956. Augmented designs, Hawaiian Planter'sRecord, 55: 191-208.

Johnson, H.W., Robinson, H.F. and Comstock, R.E.1955. Genotypic correlations in soybean and their implications in selection. Agron. J., 47: 477-483.

Joshi,N., Kumar,A. and Rather,S.A.2018. Determination of extent of variability in wheat germplasm using augmented randomized block design. International Journal of Chemical Studies, 6(3): 10741082.

Mohammadi, M., Sharifi, P., Karimizadeh, R. and Shefazadeh, M.K.2012. Relationships between Grain Yield and Yield Components in Bread Wheat under Different Water Availability (Dryland and Supplemental Irrigation Conditions). Notulae Botanicae Horti Agrobotanici Cluj, 40(1):195-200.

Sakhare, S. B. and Ghawat, N. P.2011. Correlation and path analysis in durum wheat. PKV Research Journal, 35 (1): 21- 25.

Shewry, P.2009. Increasing the health benefits of wheat. FEBS Journal,276:71-71.

Tambe,A., Mehta, D. R.,Chovatia, V. P. and Bhatiya,V.J.2013. Genetic Variability, Character Association and Path Coefficient Analysis in Durum Wheat (Triticum durumDesf.). Electronic Journal of Plant Breeding, 4(4): 1303-1308.

Yagdi, K.,2009. Path coefficient analysis of some yield components in durum wheat (Triticum durum desf.). Pak J. Bot., 41(2): 745-751.

\section{How to cite this article:}

Abhay Dashora, Urmila, Arun Gupta and Champa Lal Khatik. 2020. Assessment of Genetic Variability and Correlation for Yield and its Components Traits in Durum Wheat (Triticum durum Desf.). Int.J.Curr.Microbiol.App.Sci. 9(06): 548-554.

doi: https://doi.org/10.20546/ijcmas.2020.906.071 